\title{
Disain Prototype Pick and Place dengan Sistem Pneumatik Menggunakan Kontrol PLC Omron Tipe CP1E
}

\author{
Aswardi ${ }^{1}$, Hendri Masdi ${ }^{2}$, Kurniadi Lisman ${ }^{3}$ \\ Jurusan Teknik Elektro, Universitas Negeri Padang \\ Jln. Prof. Hamka - Air Tawar Padang 25132, Indonesia \\ aswardimt@gmail.com
}

\begin{abstract}
Industrial automation technology is developing very fast, especially in the process of taking and putting the work object. Prototype Pick and Place with a pneumatic system based on Omron PLC CP1E type was created with the aim to move the cube-shaped object with a size 4,5x4,5x4,5 $\mathrm{cm}$ and a weight of $0.2 \mathrm{~kg}$ with a speed of 12 objects of work every minute.

This tool works by using air as the driving fluid, when the sensor detects an object phototelectric work, then the double-acting cylinder pneumatic actuator will push the work object to object retrieval area. Pneumatic gripper will grip the work object, condition or not grasped the object detected by fiberoptic sensor, if an object has been gripped, the object will be removed and taken to a packaging object has been waiting for. The object then lowered into the packaging, then the object along with the packaging will be drawn with other pneumatic cylinder to the finishing area.

After testing and analysis of the prototype is made in the form of the results it can take 25 seconds to move the object 5 pieces of work along with the packaging to the finishing area, so on average each 1 objects and packaging can be moved within 5 seconds. When the minimum air pressure of $0.15 \mathrm{MPa}$ maximum lifting power of this tool is $0.632 \mathrm{~kg}$, while when the maximum air pressure of $0.7 \mathrm{MPa}$ maximum lifting capacity is $2,94 \mathrm{~kg}$.
\end{abstract}

Keywords Pick and Place, Pneumatik, PLC, photoelectric, fiberoptic

\section{PENDAHULUAN}

Kebutuhan industri pada saat sekarang ini sangatlah tinggi. Untuk memenuhi kebutuhan yang sangat tinggi tersebut serta untuk memenuhi permintaan pasar, banyak perusahaan yang memilih untuk menggunakan teknologi yang lebih efektif dan efisien, dan salah satunya adalah berupa penggunaan robot industri yang dikontrol menggunakan PLC yang berfungsi untuk menghasilkan produksi yang lebih baik dan lebih murah.

Dalam industri yang di dalamnya terdapat kegiatan memindahkan barang atau objek kerja yang panas atau objek kerja yang memiliki radiasi dari suatu tempat ke tempat lain tentunya tidak mungkin jika kegiatan pemindahan objek kerja tersebut dilakukan dengan menggunakan tenaga manusia, karena dapat dipastikan akan menciderai manusia. Untuk itu diperlukan sebuah alat yang dapat digunakan untuk mengatasi masalah tersebut dimana objek yang berbahaya tersebut dapat dipindahkan dengan aman.

Untuk saat ini, robot tercepat yang sudah dibuat dalam sistem pick and place adalah $\mathrm{ABB}$ IRB 360 flexpicker robot. ABB IRB 360 flexpicker robot dapat memidahkan objek kerja hingga 120 objek kerja per menit, atau rata-rata 2 objek setiap detiknya dengan berat maksimal objek kerja yang bisa dipindahkan adalah $3 \mathrm{Kg}$.

Berawal dari permasalahan serta fakta yang telah dikemukakan, maka penulis mencoba untuk mendesain sebuah prototype Pick and Place dengan sistem pneumatik menggunakan kontrol PLC Omron dengan kecepatan 12 objek per menitnya atau sepersepuluh dari kecepatan robot ABB IRB.360 flexpicker robot yang telah dibuat oleh ABB

Prototype ini akan bekerja mengambil, memindahkan dan menaruh objek berbentuk kontak dengan ukuran $4,5 \mathrm{~cm} \times 4,5 \mathrm{~cm} \times 4,5 \mathrm{~cm}$ dengan berat $0,2 \mathrm{Kg}$ dengan perpindahan sejauh 20 $\mathrm{cm}$ ke dalam kemasan objek yang berukuran $6 \mathrm{~cm} \mathrm{x}$ $6 \mathrm{~cm} \times 6 \mathrm{~cm}$, berbentuk kotak yang bagian atasnya terbuka dengan perpindahan ke finishing area sejauh $7 \mathrm{~cm}$. Jadi total perpindahan objek kerja menjadi $27 \mathrm{~cm}$. PLC yang akan di pakai nantinya adalah PLC merek Omron dengan tipe CP1E. Pemakaian PLC produksi omron karena di 
Indonesia banyak industri yang menggunakan PLC omron, selain itu kebanyakan kampus dan sekolah kejuruan menggunakan PLC keluaran omron, jadi prototype ini akan lebih mudah dipelajari. Dan penggunaan tipe CP1E karena PLC omron tipe ini komunikasinya menggunakan USB dan harganya lebih murah dibanding PLC omron tipe lain yang juga sudah menggunakan USB untuk komunikasinya.

Berdasarkan permasalahan di atas, penulis mencoba merancang sebuah prototype Pick and Place dengan sistem pneumatik menggunakan kontrol PLC Omron CP1E yang cepat dalam memindahkan objek berbentuk kubus dengan ukuran $4,5 \times 4,5 \times 4,5 \mathrm{~cm}$ dengan berat $0,2 \mathrm{Kg}$ dengan kecepatan 12 objek setiap manitnya.

\section{Prinsip Dasar Sistem}

Afgianto (2004:9) menyatakan bahwa "sebuah PLC adalah sebuah alat yang dapat digunakan untuk menggantikan rangkaian sederetan relai yang dijumpai pada sistem kontrol konvensional

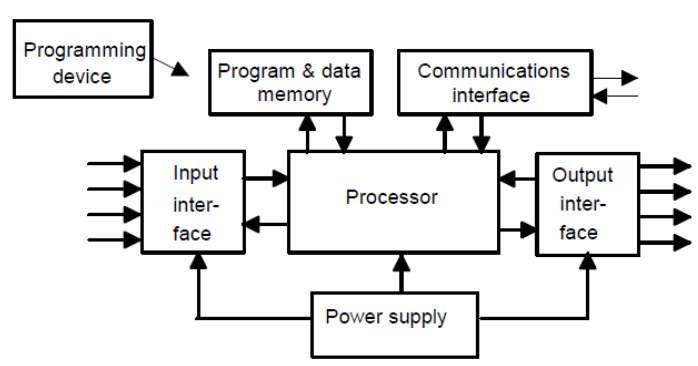

Gambar 1. Arsitektur PLC

Umumnya sebuah PLC mempunyai lima komponen dasar yaitu; (1) Unit prosesor atau central processing unit (CPU) yang di dalamnya berisi mikroprosesor yang mampu menginterpretasikan sinyal-sinyal masukan dan melakukan tindakantindakan pengontrolan, sesuai dengan program yang tersimpan di dalam memori. (2) Unit catu daya yang diperlukan untuk mengubah tegangan arus bolak-balik (ac) dari sumber menjadi tegangan arus searah (dc) yang dibutuhkan oleh prosesor dan rangkaian-rangkaian di dalam modul-modul antarmuka masukan dan keluaran. (3) Perangkat Pemrograman digunakan untuk memasukan program yang dibutuhkan ke dalam memori. Unit memori merupakan tempat menyimpan program yang akan digunakan untuk melaksanakan tindakan-tindakan pengontrolan yang disimpan mikroprosesor, (4) Bagian masukan dan keluaran merupakan antarmuka dimana prosesor menerima informasi dari dan mengkomunikasikan informasi kontrol ke perangkat-perangkat diluar.

PLC Omron tipe CP1E adalah tipe PLC buatan Omron yang terdiri dari 2 tipe yaitu tipe $\mathrm{E}$ dan tipe $\mathrm{N}$. Tipe E merupakan model dasar atau model standar yang digunakan operasi kontrol standar yang menggunakan instruksi dasar, instruksi perpindahan, perhitungan dan instruksi perbandingan. Sedangkan CP1E tipe $\mathrm{N}$ adalah model aplikasi yang mendukung koneksi pada terminal pemrograman inverter dan pengendali servo. Tiap tipe PLC ini tersedia dalam jumlah input yang beragam 20, 30, atau 40 terminal I/O.

Aktuator pneumatik memiliki arah gerak maju (langkah maju) dan arah gerak mundur (langkah mundur). Tekanan udara yang bekerja dalam silinder menyebabkan batang piston bergerak maju atau mundur. Jika tekanan pada sisi berlawanan diabaikan maka besarnya gaya yang bekerja pada piston adalah:

$$
F=p \times A
$$

Pada langkah maju gaya dipengaruhi oleh luas penampang silinder dan luas penampang silinder tergantung pada diamter dalam.

$$
A=\frac{\pi}{4} D^{2}
$$

Gaya langkah maju yang bekerja pada silinder sebagai berikut:

$$
F=\frac{\pi}{4} D^{2} \cdot p
$$

Besarnya gaya pada langkah mundur dipengaruhi diameter dalam silinder dan diameter luar batang piston.

$$
A=\frac{\pi}{4}\left(D^{2}-d^{2}\right)
$$

Sehingga gaya langkah mundur yang bekerja pada silinder adalah:

$$
F=p \cdot \frac{\pi}{4}\left(D^{2}-d^{2}\right)
$$

Setelah didapatkan besarnya gaya yang bekerja pada silinder maka besarnya massa benda yang 
mampu didorong silinder juga bisa dihitung menggunakan rumus berikut ini.

$$
\begin{aligned}
\mathrm{F}=\mathrm{m} \times \mathrm{g} \\
\mathrm{m}=\mathrm{F} / \mathrm{g}
\end{aligned}
$$

Jika massa benda telah ditentukan, maka besarnya tekanan terkecil yang diberikan untuk mendorong pneumatik, agar pneumatik mampu mendorong benda juga dapat dihitung sebagai berikut.

$$
\begin{gathered}
\mathrm{p}=\mathrm{F} / \mathrm{A} \\
\mathrm{p}=(\mathrm{m} \times \mathrm{g}) / \mathrm{A}
\end{gathered}
$$

\section{Komponen Utama Sistem}

Katup 5/2 solenoid tunggal mempunyai pegas untuk mengembalikan katup ke posisi netral.

\section{Prinsip Kerja Katup 5/2 Solenoid Tunggal}

Posisi Awal

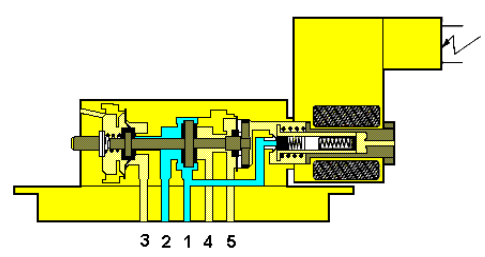

Posisi Aktif

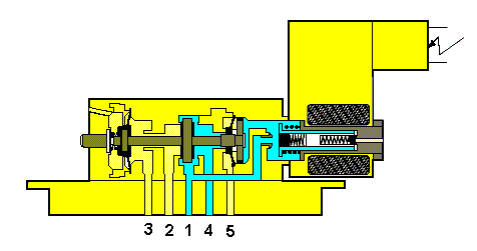

Gambar 2. Prinsip kerja katub 5/2 solenoid tunggal

Katup 5/2 solenoid ganda memiliki 2 solenoid dan tidak memiliki pegas pengembali. Mengaktifkan katup ke posisi yang diinginkan dengan memberi tegangan pada salah satu solenoid yang akan mengaktifkan katup tersebut.

\section{Prinsip Kerja Katup 5/2 Solenoid Ganda}

- Posisi Y2 terakhir aktif

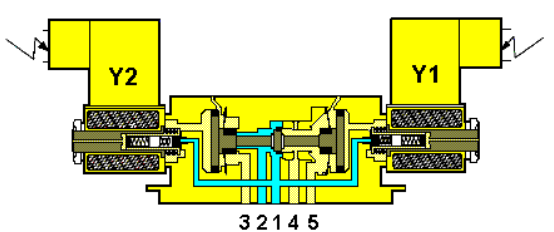

- Posisi Y1 aktif

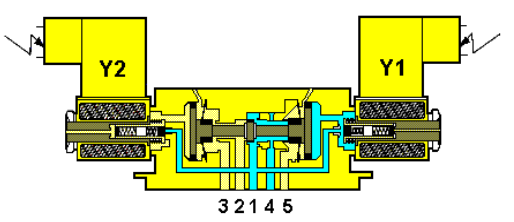

Gambar 3. Prinsip kerja katub 5/2 solenoid ganda

Kompresor berfungsi sebagai sumber udara bertekanan dengan cara menghisap dan memampatkan udara tersebut kemudian disimpan di dalam tangki udara untuk disuplai kepada pemakai (sistem pneumatik). Kompressor dilengkapi dengan tabung untuk menyimpan udara bertekanan, sehingga udara dapat mencapai jumlah dan tekanan yang diperlukan.

Unit Filter-Regulator-Lubricator (FRL) merupakan salah satu komponen yang penting dan paling dicari pada sistem pneumatik. FRL terpasang pada tiap sambungan pneumatik menyiapkan pengguna dengan pertahanan terakhir melawan kontaminasi pada udara yang akan dipakai. Sebuah peralatan penyimpan energi, rendah bising dan meningkatkan umur dari peralatan atau mesin yang digunakan

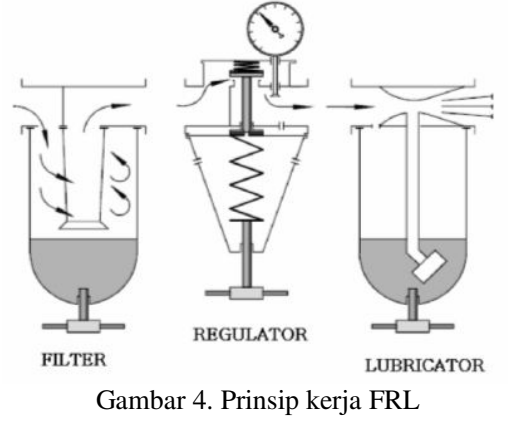

Reed switch adalah sensor yang bekerja berdasarkan pada medan magnet yang dipasang pada piston silinder pneumatik. Pada alat penggerak berupa silinder, biasanya telah dilengkapi dua buah sensor ini, yang berfungsi untuk mendeteksi gerakan silinder ketika naik atau turun, letaknya ada di bagian luar bawah dan luar atas pada silinder 

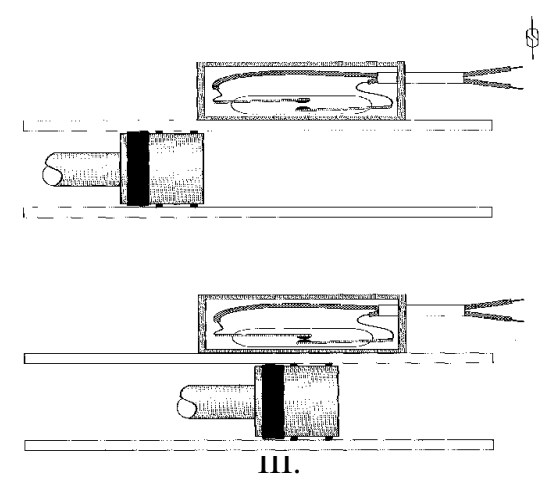

Gambar 5. Prinisip kerja reed switch

Photo sensor yang digunakan nanti adalah tipe difusi. Sensor ini nanti akan mendeteksi objek untuk didorong menggunakan pneumatik pendorong. Jadi sensor ini akan dapat merasakan keberadaan objek kerja.

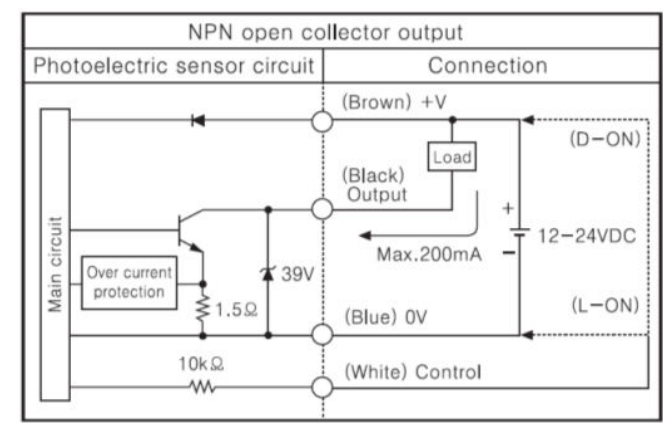

Gambar 6. Pembebanan photoelectric sensor

Tipe yang akan digunakan pada alat yang akan dibuat ini adalah tipe NPN. Perbedaannya dengan PNP hanya terletak pada pembebanan. Kemudian photoelectric ini dapat aktif dengan kondisi Light $O N$ atau Dark $O N$ tergantung dari kabel yang berwarna putih dihubungkan ke negatif atau positif catu daya. Light $O N$ jika dihubungkan ke negatif catu daya dan Dark $O N$ jika dihubungkan ke positif catu daya.

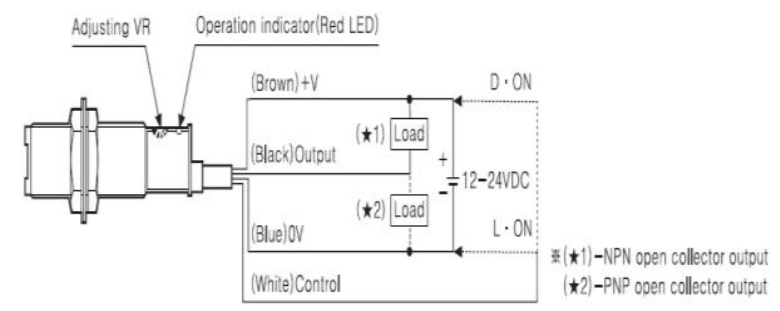

Gambar 7. Pengawatan photoelectric sensor

Fiberoptic sensor yang akan dipakai adalah tipe difusi sama seperti sensor photoelectric di atas.
Sensor ini nantinya dipasang untuk mendeteksi apakah gripper pneumatik sudah mengenggam objek kerja atau belum.

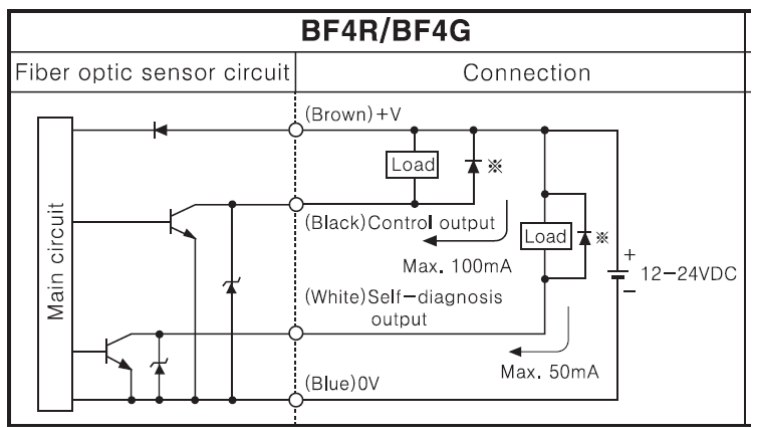

Gambar 8. Pembebanan fiberoptic sensor

Fiberopptic sensor ini berfungsi sebagai penerima sinyal dari kabel fiberoptic. Ketika ada objek kerja, kabel fiberoptic akan mengirim berkas cahaya ke sensor fiberoptic yang kemudian akan dianalisa oleh sensor fiberoptic yang akan memberikan informasi tentang kondisi beban apakah beban diaktifkan atau tidak.

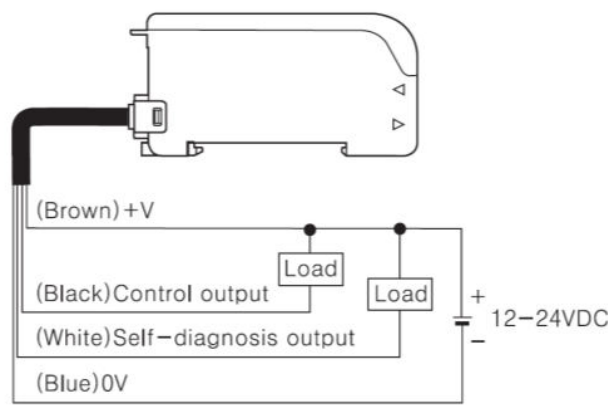

Gambar 9. Pengawatan fiberoptic sensor

Jadi fiberopptic sensor hanya berfungsi sebagai penerima sinyal dari kabel fiberoptic. Ketika ada objek kerja kabel fiberoptic akan mengirim berkas cahaya ke sensor fiberoptic yang selanjutnya akan dianalisa oleh sensor fiberoptic dan akan memberikan informasi kondisi pada beban apakah beban diaktifkan atau tidak

\section{Metode Perancangan}


Dalam metode akan dibahas tentang perancangan dan pembuatan alat yang meliputi perancangan alat, blok diagram

\section{Perancangan Alat}

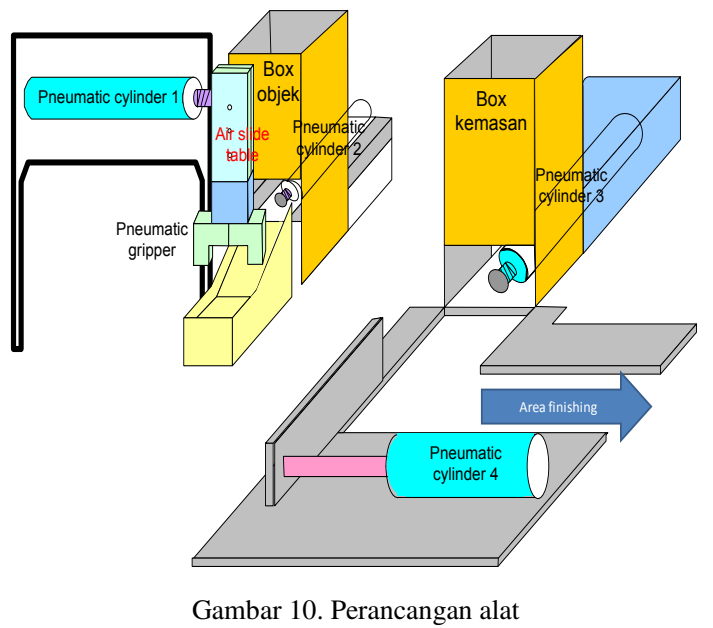

Blok diagram

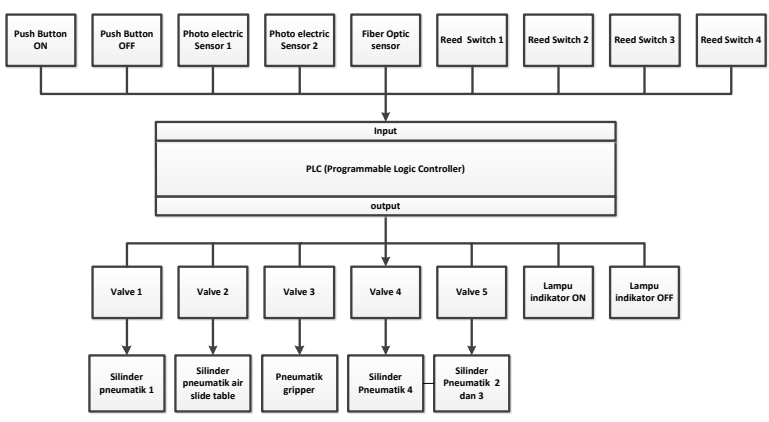

Gambar 11. Blok diagram sistem

Perancangan alat diawali dengan rancangan sistem keseluruhan yang terdiri dari rancangan input, proses dan output dari sistem. Selanjutnya diikuti dengan rancangan untuk setiap blok dari sistem yang terdiri dari blok input dan output serta rancangan pengendali utama. Setiap rancangan blok berisikan perancangan tentang sinyao I/O dan proses kerja blok, serta kapasitas komponen yang digunakan. Bagian akhir dari rancangan ini adalah rancangan program (software) yang digunakan untuk aktivasi sistem.

\section{Prosedur Pengujian}

PLC yang digunakan adalah Omron tipe CP1E. Input berupa Push button ON berfungsi untuk membuat semua input output pada alat ini berada dalam kondisi standby. Artinya PLC baru bisa mengaktifkan output ketika menerima sinyal dari sensor-sensor yang ada setelah push button ON ditekan sesaat. Apabila push button $O N$ belum ditekan walaupun sensor mendeteksi adanya benda maka tidak ada pengaruhnya pada output-output yang ada seperti valve pneumatik dan lampu indikator. Sedang push button OFF berfungsi untuk membuat sistem kembali dalam kondisi standby.

Sistem bekerja ketika objek kerja terdeteksi oleh sensor photoelectric 1 setelah tombol ON ditekan sesaat, jika tombol ON belum ditekan meski sensor photoelectric 1 mendeteksi objek, tidak akan membuat sistem bekerja. Setelah terdeteksi silinder pneumatik 2 akan mendorong objek ke luar dari wadah penampungan objek ke tempat pengambilan objek oleh gripper sedang silinder pneumatik 3 akan mendorong kemasan ke posisinya.

Photoelectric sensor 2 akan aktif ketika objek sampai ke tempat pengambilan objek dan mengaktifkan pneumatik air slide table untuk menurunkan pneumatik gripper ke posisi objek. Gripper akan mencengkram objek kerja dan mengangkat objek kerja dengan pneumatik air slide table dan membawa objek kerja ke tempat kemasan objek berada dengan memanfaatkan dorongan dari silinder pneumatik 1 yang aktif setelah objek tercengkram dan terangkat.

Pada waktu di posisi kemasan objek berada, pneumatik air slide table akan menurunkan objek bersama dengan gripper dan akan melepaskan objek kerja. Setelah objek masuk ke dalam kemasan, pneumatik gripper akan diangkat naik oleh pneumatik air slide table. Setelah gripper naik silinder pneumatik 4 akan menarik objek kemasan yang berada didalamnya sudah terdapat objek kerja ke finishing area. Setelah itu pneumatik air slide table dan gripper akan dibawa ke posisi awal oleh silinder pneumatik 1 sampai photo electric sensor 1 mendeteksi objek kembali dan proses akan berulang hingga tidak ada lagi objek yang terdeteksi atau sampai ditekannya push button OFF. Pencatatan waktu dilakukan secara berulang untuk satu kali proses untuk kemudian dilakukan perhitungan waktu rata-rata (mean) untuk satu kali proses pemindahan objek. Waktu rata-rata yang diperlukan dijadikan acuan sebagai 
waktu yang diperlukan untuk memindahkan objek pada sistem ini.

\section{Hasil dan Pembahasan}

Prototype ini dibuat untuk dapat menampung 5 objek kerja sekali siklus, jadi untuk mendapatkan hasil sesuai dengan tujuan dari penelitian ini nantinya hasil dari pengujuan kecepatan dapat dikalkulasikan untuk mendapatkan jumlah objek yang dapat dipindahkan setiap detiknya. Setelah dilakukan perhitungan selama pengujian, dapatlah bahwa prototype ini dapat melakukan proses pemindahan objek mulai dari mendorong objek ke area kerja, kemudian mengangkat objek, lalu diteruskan dengan membawa objek ke tempat kemasan, selanjutnya melepas objek, dan terakhir menarik objek beserta kemasannya ke finishing area dan kembali ke posisi standby diperlukan waktu 25 detik untuk 5 buah objek kerja beserta kemasannya, jadi rata-rata tiap 1 objek dan kemasannya dapat dipindahkan dalam waktu 5 detik.

Dari 5 kali pegujian yang dilakukan, semua objek berhasil dipindahkan dengan baik, tepat dan pas masuk ke dalam kemasan yang disediakan. Ini ditunjukkan bahwa alat yang dibuat ini dapat memindahkan objek ke dalam kemasannya dengan cepat dan tepat. Dengan hasil pengujian bahwa 1 objek dipindahkan dalam waktu 5 detik didapatlah bahwa dalam satu menit prototype ini dapat memindahkan objek kerja sebanyak 12 buah, dan hasil ini sesuai dengan tujuan dari pembuatan prototype ini.

Untuk mengetahui besarnya daya angkat maksimum dan minimum alat ini dapat dilihat dari besarnya gaya yang dihasilkan oleh pneumatik air slide table. Daya angkat ini ditunjukkan ketika pneumatik air slide table dalam kondisi langkah mundur. Berdasarkan rumus $\mathrm{F}=\mathrm{m} . \mathrm{g}$ dimana $\mathrm{F}$ adalah besarnya gaya yang dihasilkan, $m$ mewakili masa objek dan $g$ mewakili percepatan gravitasi yang bernilai konstan $9,8 \mathrm{~m} / \mathrm{s}^{2}$ Besarnya tekanan minimum yang diperlukan untuk menggerakkan pneumatik air slide table sebesar $0.15 \mathrm{MPa}$, dan menghasilkan gaya sebesar 6,32 N. Besarnya daya angkat maksimum ketika tekanan minimum ditentukan dengan cara:

$$
\mathrm{F}=\mathrm{m} \cdot \mathrm{g}
$$

\section{$6,32 \mathrm{~N}=\mathrm{m} \times 10 \mathrm{~m} / \mathrm{s}^{2}$

$$
\begin{aligned}
\mathrm{m} & =6,32 \mathrm{~N} / 10 \mathrm{~m} / \mathrm{s}^{2} \\
& =0,632 \mathrm{~kg}
\end{aligned}
$$

Sedangkan daya angkat maksimum ketika tekanan udara yang masuk ke pneumatik air slide table juga bernilai maksimum, yaitu sebesar 0,7 MPa. Dengan gaya yang dihasilkan sebesar 33,6 N, nilai daya angkat maksimum ketika tekanan udaranya maksimum adalah. $29,4 \mathrm{~N}=\mathrm{m} \times 10 \mathrm{~m} / \mathrm{s}^{2}$ akan diperoleh $\mathrm{m}=2.94 \mathrm{~kg}$

Jadi ketika tekanan udara minimum sebesar $0,15 \mathrm{MPa}$ daya angkat maksimumnya adalah 0,632 $\mathrm{kg}$, sedang ketika tekanan udara maksimum sebesar $0,7 \mathrm{MPa}$ daya angkat maksimumnya adalah $2,94 \mathrm{~kg}$.

\section{Kesimpulan dan Saran}

Mengacu pada hasil pengukuran dan analisa yang telah dilakukan di atas. diperoleh beberapa kesimpulan berkaitan dengan prototype yang dibuat. 1) Alat ini dapat bekerja memindahkan Objek kerja yang berjumlah 5 buah dalam waktu 25 detik. Kecepatan pemindahan ojek adalah 12 objek dalam waktu 1 menit. 2) kemampuan peralatan mengangkat beban adalah sebesar 0,632 Kg pada tekanan udara minimal sebesar $0,15 \mathrm{Mpa}$, dan 2,94 Kg pada tekanan udara maksimal sebesar 0,7 Mpa..

\section{Daftar Pustaka}

[1] Barber, Anthony. 1997. “Pneumatic Handbook 8th Edition”. England: Elsevier Science \& Technology Books

[2] Bolton, W. 2006. Programmable Logic Controller Fourth edition. London : Elsevier Newnes

[3] F. Ebel, P. Croser. 2002. "Pneumatic Basic Level" Germany: Festo Didactic

[4] Katsuhiko, Ogata. 1995. "Teknik Kontrol Automatik (Sistem Pengaturan)". (Edi Laksono. Tejemahan). Jakarta: Erlangga

[5] Krist, Tomas. 1993. "Dasar-Dasar Pneumatik". (Purnomo Wahyu Indarto. Terjemahan). Jakarta: Erlangga. Buku asli diterbitkan tahun 1979.

[6] Putra, Afgianto Eka. 2004. "PLC Konsep, Pemograman, dan Aplikasi". Yogyakarta: Gava Media.

[7] Said, Hanif. 2012. "Aplikasi PLC dan Sistem Pneumatik pada Manufaktur Industri". Yogyakarta: Andi

[8] Yogaswara, Eka. 2012. "Proses Dasar Pneumatik dan Hidraulik". Bandung: Armico 